Proc. Estonian Acad. Sci. Geol., 1999, 48, 2, 110-115

\title{
FACIES DISTRIBUTION OF EARLY CAMBRIAN MOLLUSCS IN ESTONIA
}

\author{
Kaisa MENS ${ }^{\mathrm{a}}$ and Mare ISAKAR ${ }^{\mathrm{b}}$
}

\begin{abstract}
${ }^{a}$ Institute of Geology, Tallinn Technical University, Estonia pst. 7, 10143 Tallinn, Estonia
${ }^{\mathrm{b}}$ Museum of Geology, University of Tartu, Vanemuise 46, 51014 Tartu, Estonia; mi@ut.ee
\end{abstract}

Received 5 April 1999, in revised form 12 April 1999

\begin{abstract}
The helcionelloid mollusc Anabarella was recently found from the Kestla Member of the Lontova Formation in the Vanamõisa F-149 core at a depth of $123 \mathrm{~m}$. The appearance of Early Cambrian molluscs Aldanella and Anabarella in Estonia was connected with the maximum expansion of the Cambrian palaeobasin on the East European Platform. In the Lontova Stage the molluscs occurred in the facies deposited in quiet hydrodynamic conditions which were typical of the maximum marine transgression characterized by extensive clay accumulation far from the coast.
\end{abstract}

Key words: Lower Cambrian, Estonia, sea level fluctuations, mollusc distribution, Aldanella, Anabarella.

\section{PALAEONTOLOGICAL RECORDS}

The oldest known Estonian mollusc was first described by Öpik (1926) as Pleurotomaria? kunda from the Lower Cambrian Lontova Stage. Öpik questioned the generic assignment of this find based on a single pyritized internal mold. He recognized it as the oldest known gastropod and later (Öpik, 1956) as congeneric with Pleurotomaria attleborensis Shaler \& Foerste, 1888. Subsequently, Rozanov (1973) assigned new finds of this species from Estonia to the genus Aldanella Vostokova, 1962. In his opinion, the species from the Lontova Stage is very close to Aldanella rozanovi Missarzhevsky, 1966, very common in the Tommotian of the Siberian Platform. All later new finds of Aldanella from drill cores in Estonia and from Kunda (Lontova) quarry have been described by Posti (1978) and Lendzion \& Posti (1983) as Aldanella kunda (Öpik, 1926). A recent identification of Anabarella (Helcionelloida) by Mare 
Isakar from the Kestla Member of the Lontova Formation in the Vanamõisa F-149 core is a significant addition to the distribution of molluscs on the East European Platform (Lendzion, 1977; Føyn \& Glaessner, 1979). Up to now it was thought that Aldanella predominated in eastern North America, northwestern Siberia, and on the East European Platform (Poland, Norway, Estonia), while Anabarella was most abundant in eastern Siberia and Mongolia, being rare in North America, Poland, and South China (Gubanov, 1998). Recently Anabarella was found also from the Estonian Lower Cambrian.

\section{GEOLOGICAL SETTING}

The oldest Cambrian rocks in Estonia were formed during the Baltic stage of the basin development, in the pretrilobite Early Cambrian (Mens, 1981). The beginning of the Early Cambrian sedimentation in the studied area corresponds to the Platysolenites antiquissimus Zone in the current use (Mens et al., 1990) and/or to the Asteridium tornatum-Comasphaeridium velvetum Zone, distinguished by Moczydłowska (1991) in Poland and defined as the Lontova Stage over a large part of the East European Platform (Mens et al., 1990). The older deposits of the Sabellidites cambriensis Zone, characterized by the occurrence of the acritarch Teophipolia lacerata and Retisphaeridium densum, are lacking in Estonia (Paškevičene, 1980; Mens \& Pirrus, 1997a).

The Lontova deposits unconformably overlie stratigraphical units of different age, including those of the crystalline basement. In Lontova time sedimentation took place during a marine transgression that advanced from the east and most of present-day Estonia was submerged (Fig. 1) (Mens \& Pirrus, 1997b). A relatively small amount of coarse clastic material and the small portion of sandstone in the basal beds of the stage (except the westernmost area) point to slow transgression and level relief of both the basin bottom and the surrounding source area.

The stratigraphical completeness and thickness of the Lontova Stage are variable. The rocks are thickest $(c .90 \mathrm{~m})$ in northeastern Estonia, thinning southwards due to postsedimentation denudation (Kala et al, 1981).

The Lontova Stage is represented by siliciclastic rocks with a clear lateral replacement due to changes in depositional conditions. Argillaceous rocks are prevailing in eastern and central Estonia, while sandstones dominate in western mainland Estonia and on the islands of the West Estonian Archipelago. As a result, two formations have been distinguished in the Lontova Stage: the Lontova Formation in the east and the Voosi Formation in the west (Fig. 1) (Kala et al., 1981).

The Lontova Formation occurs in northern, eastern, and central Estonia (Fig. 1) and is represented by greenish-grey and variegated argillaceous rocks with interbeds of coarse- to fine-grained sandstone in the lower- and uppermost 


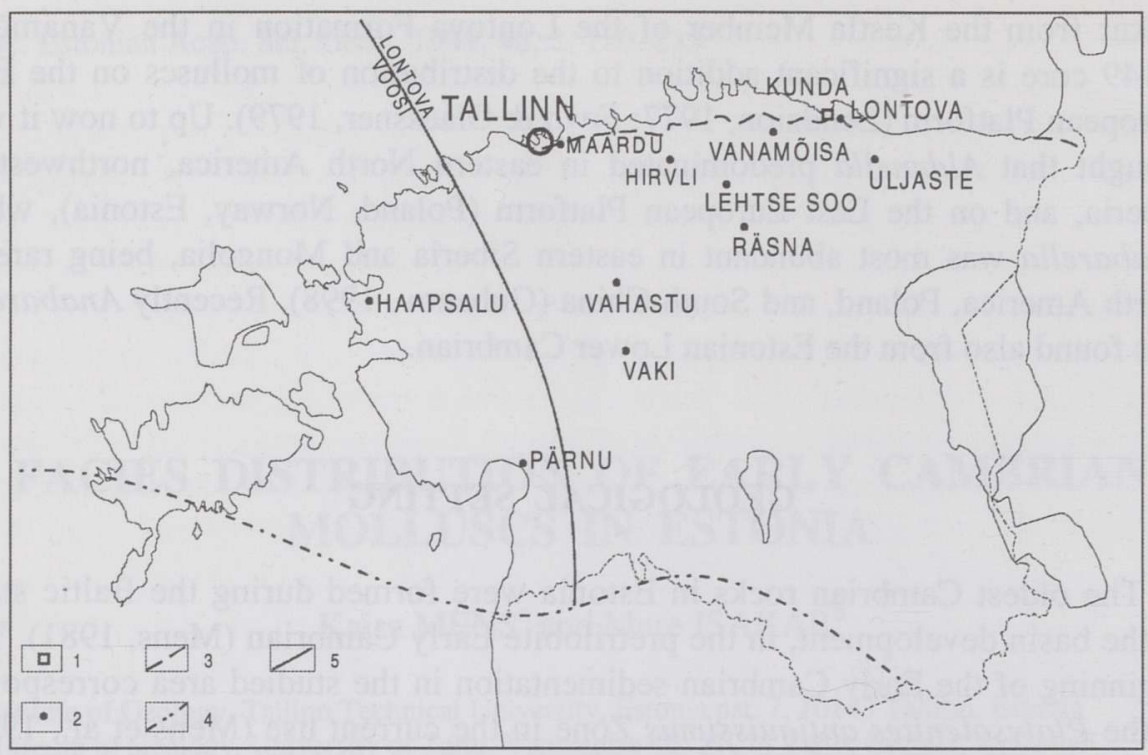

Fig. 1. The distribution of the Lontova and Voosi formations and boreholes with mollusc finds. 1, outcrop; 2 , borehole; 3 , northern margin of the Ordovician cover; 4 , southern extension limit of the Lontova Stage; 5, boundary between the Voosi and Lontova formations (by Mens \& Pirrus, 1997a).

parts. According to the ratio of rock types, the formation is subdivided upwards into the Sämi, Mahu, Kestla, and Tammneeme members (Fig. 2) (Kala et al., 1981).

The Voosi Formation consists mostly of quartzose sandstone that is the dominant type of rocks on the islands of the West Estonian Archipelago. Argillaceous rocks are of minor importance and associate mostly with the upper part of the formation in mainland Estonia. The Voosi Formation comprises (from below) the Taebla, Kasari, and Paralepa members (Fig. 2) (Mens \& Pirrus, 1997a).

The Lower Cambrian (so-called pretrilobite) stratigraphy and correlation are mainly based on acritarchs on the East European Platform (e.g. Volkova, 1968; Mens \& Pirrus, 1977; Moczydłowska, 1991), whereas skeletal fossils are rare and scattered; representatives of Sabellidites and Platysolenites predominate.

Molluscs have been little used in Lower Cambrian stratigraphy of the East European Platform, particularly due to their rarity, facies control, and restricted geographical distribution. However, they are widely used in interregional correlation (e.g. Rozanov, 1973; Landing, 1992).

The Lontova Stage (= Platysolenites antiquissimus Zone) includes (from the base) the beds with Sabellidites cambriensis, Platysolenites lontova, Aldanella kunda, and Platysolenites spiralis, according to the first appearance of the 


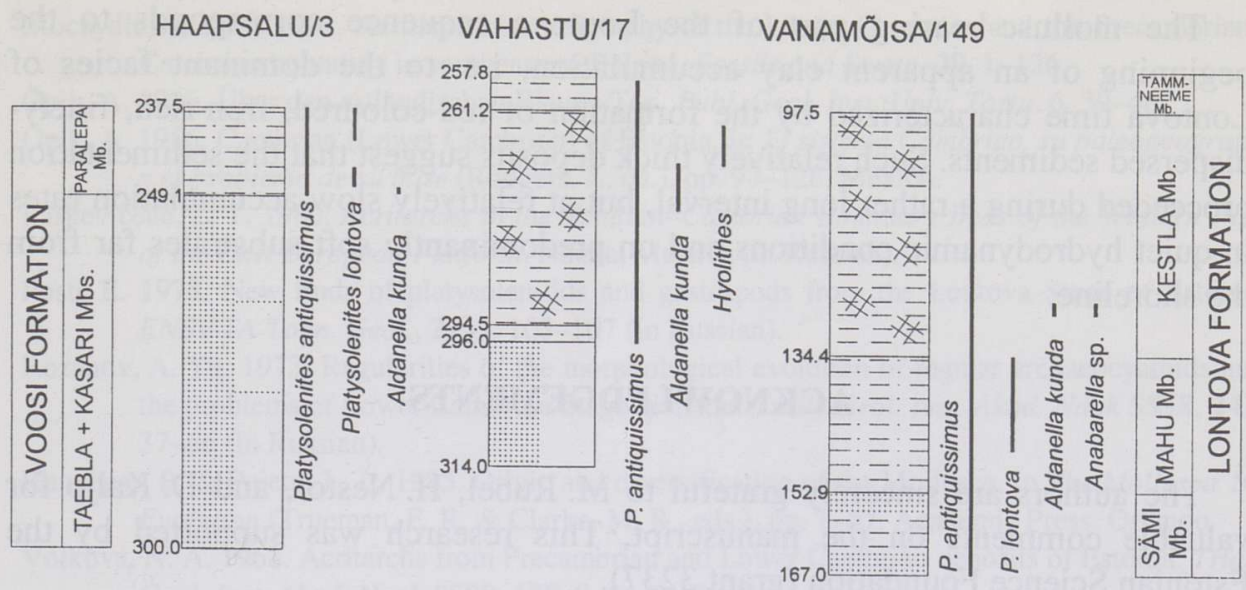

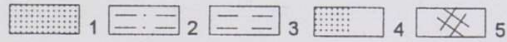

Fig. 2. The distribution of selected fossils in sections of the Lontova Stage. Diversification of fossils was connected with the prevalence of claystone (Kestla and Paralepa members). 1, sandstone; 2, silty claystone; 3, claystone prevalence; 4, uncored interval (poorly cemented sandstone); 5 , variegated deposits.

corresponding taxa (Mens \& Posti, 1984). This succession can be observed in the Lontova Formation as well as in the Voosi Formation, which provides a good basis for detailed biostratigraphical subdivision.

\section{PALAEOENVIRONMENT}

The distribution of fossils, including molluscs, in the Lontova sequence shows a distinct facies control (Mens \& Posti, 1984). According to palaeoecological data by Runnegar \& Pojeta (1985), older Cambrian molluscs probably preferred shallow sublittoral environments. Representatives of Estonian molluscs seem to be completely absent in the nearshore environment characterized by fine-grained light-coloured sands, lack of pyritized trace fossils, and the occurrence of the Skolithos-Planolites ichnoassemblage. Such deposits of the Taebla Member of the Voosi Formation are interpreted here as the deposits of well-aerated highenergy conditions formed in a basin with a relatively flat bottom. Molluscs are also lacking in the Mahu and Kasari members characterized by interbedding of grey sand- and claystones. Sandstones are unsorted at some levels and yield flat small pebbles sporadically. Ichnofossils are represented by pyritized and Planolites-type forms. Such variable depositional conditions, accompanying the initial transgressive phase as well as the regressive phase (Tammneeme Member) in basin development, have been unfavourable for molluscs. 
The mollusc-bearing part of the Lontova sequence corresponds to the beginning of an apparent clay accumulation, i.e. to the dominant facies of Lontova time characterized by the formation of red-coloured, iron-rich, finelydispersed sediments. Such relatively thick deposits suggest that the sedimentation proceeded during a rather long interval, but at relatively slow accumulation rates in quiet hydrodynamic conditions and on predominantly soft substrates far from the shoreline.

\section{ACKNOWLEDGEMENTS}

The authors are sincerely grateful to M. Rubel, H. Nestor, and D. Kaljo for valuable comments on the manuscript. This research was supported by the Estonian Science Foundation (grant 3237).

\section{REFERENCES}

Gubanov, A. P. 1998. The Early Cambrian molluscs and their palaeogeographical implications. Schriften des Staatlichen Museums für Mineralogie und Geologie zu Dresden, 9, 139.

Føyn, S. \& Glaessner, M. F. 1979. Platysolenites, other animal fossils, and the PrecambrianCambrian transition in Norway. Norsk Geologisk Tidsskrift, 59, 25-46.

Kala, E., Kajak, K., Mens, K. \& Pirrus, E. 1981. Lithostratigraphy and facies of the Lontova Stage in Estonia. ENSV TA Toim. Geol., 30, 4, 137-147 (in Russian).

Landing, E. 1992. Lower Cambrian of southeastern Newfoundland: Epeirogeny and Lazarus faunas, lithofacies-biofacies linkages, and the myth of a global chronostratigraphy. In Origin and Early Evolution of the Metazoa (Lipps, J. H. \& Signor, P. W., eds.), pp. 283309. Plenum Press, New York.

Lendzion, K. 1977. First gastropod fauna from the Klimontovian Stage (Lower Cambrian) of the South-Eastern Poland. Kwartalnik Geol., 21, 239-243.

Lendzion, K. \& Posti, E. 1983. Gastropoda. In Upper Precambrian and Cambrian Palaeontology of the East-European Platform. Contribution of the Soviet-Polish Working Group on the Precambrian-Cambrian Boundary Problem (Urbanek, A. \& Rozanov, A. Y., eds.), pp. 123-126. Publishing House Wydawnictwa Geologiczne, Warszawa.

Mens, K. 1981. On the Early Cambrian sedimentation stages in the East Baltic area. Izv. Akad. Nauk SSSR, Ser. Geol., 3, 83-90 (in Russian).

Mens, K., Bergström, J. \& Lendzion, K. 1990. The Cambrian System on the East European Platform, correlation chart and explanatory notes. IU Geol. Sci. Publ., 25.

Mens, K. \& Pirrus, E. 1977. Stratotypes of the Cambrian Formations of Estonia. Valgus, Tallinn (in Russian).

Mens, K. \& Pirrus, E. 1997a. Cambrian. In Geology and Mineral Resources of Estonia (Raukas, A. \& Teedumäe, A., eds.), pp. 39-51. Estonian Academy Publishers, Tallinn.

Mens, K. \& Pirrus, E. 1997b. Vendian-Tremadoc clastogenic sedimentation basins. In Geology and Mineral Resources of Estonia (Raukas, A. \& Teedumäe, A., eds.), pp. 184-191. Estonian Academy Publishers, Tallinn.

Mens, K. \& Posti, E. 1984. Distribution and correlation significance of organic remains in the Baltic Series of Estonia. In Stratigrafiya drevnepaleozoiskikh otlozhenij Pribaltiki (Männil, R. \& Mens, K., eds.), pp. 5-17. Inst. Geol. Akad. Nauk ESSR, Tallinn (in Russian). 
Moczydłowska, M. 1991. Acritarch biostratigraphy of the Lower Cambrian and the PrecambrianCambrian boundary in southeastern Poland. Fossils and Strata, 29, 1-126.

Öpik, A. 1926. Über den estländischen Blauen Ton. Publ. Geol. Inst. Univ. Tartu, 6, 39-46.

Öpik, A. 1956. Cambrian (Lower Cambrian) of Estonia. In El sistema Cāmbrico, su paleogeografia y el problema de su base (Rodgers, J., ed.), pp. 97-126. Mexico.

Paškevičene, L. T. 1980. Acritarchs in the Vendian-Cambrian Boundary Beds of the Western Part of the East European Platform. Nauka, Moskva (in Russian).

Posti, E. 1978. New finds of platysolenitids and gastropods from the Lontova Stage of Estonia. ENSV TA Toim. Geol., 27, 3, 103-107 (in Russian).

Rozanov, A. Yu. 1973. Regularities of the morphological evolution of regular archaeocyathids and the problems of Lower Cambrian Stage division. Trudy Geol. Inst. Akad. Nauk SSSR, 241, 37-66 (in Russian).

Runnegar, B. \& Pojeta, J., Jr. 1985. Origin and diversification of the Mollusca. In The Mollusca 10 , Evolution (Trueman, E. R. \& Clarke, M. R., eds.), pp. 1-57. Academic Press, Orlando.

Volkova, N. A. 1968. Acritarchs from Precambrian and Lower Cambrian deposits of Estonia. Trudy Geol. Inst. Akad. Nauk SSSR, 188, 8-36 (in Russian).

\title{
VARAKAMBRIUMI MOLLUSKITE FATSIAALNE LEVIKUPILT EESTIS
}

\author{
Kaisa MENS ja Mare ISAKAR
}

Eesti pretrilobiitse varakambriumi läbilõikes on molluskid esindatud kahe perekonnaga Aldanella ja Anabarella. Nende esinemist läbilõikes on oluliselt piiranud settimise tingimused, esmajärjekorras basseini hüdrodünaamika. Molluskitele kõige sobivamaks elukeskkonnaks oli rannast kaugemal asunud suhteliselt sügavaveeline rahulik settimisala, mis oli iseloomulik transgressiooni stabiilsele faasile Lontova eal.

\section{ФАЦИАЛЬНОЕ РАСПРЕДЕЛЕНИЕ РАННЕКЕМБРИЙСКИХ МОЛЛЮСКОВ В ЭСТОНИИ}

\author{
Кайса МЕНС и Маре ИСАКАР
}

В дотрилобитовых нижнекембрийских отложениях Эстонии найдены моллюски двух родов - Aldanella и Anabarella. Их распределение как по площади, так и по разрезу определялось фациальной обстановкой осадконакопления, т. е. седиментацией тонкодисперсного материала в удаленных от берега глубоководных зонах с низкой гидродинамической активностью. Эти условия имели место в фазе максимальной лонтоваской трансгрессии. 